\title{
Historical or Textual Archaeology An Archaeology of Critical Rereading
}

\author{
Frands Herschend
}

\begin{abstract}
Based on a discussion of the relationship between history and archaeology, the author proposes a critical analysis of both written and material sources. All sources are considered textual and should be analysed (reread) on three levels: the conceptual, the intentional and the structural. In an example - an analysis of the meaning of the concept 'land' the value of the analysis is shown to be the formation of a discursive and meaningful concept in an evolutionary and additive production of knowledge. Rereading ought to be the methodological approach of textual archaeology.
\end{abstract}

Frands Herschend, Department of Archaeology, Uppsala University. SE-753 10 Uppsala, Sweden.

Living in a time when research within the humanities is likely in part to reflect those whom we love, it is not surprising that some may feel secure enough to state that archaeology is a craft or a legitimate academic discipline. Such activities may, however, be linked to research by means of a reasonable methodological foundation, and as such the insights into our minds which may present themselves to the reader will not be embarrassing. Today's situation is the consequence of the theoretical discussion around 1990, in which those who participated exhausted themselves by trying to alter the foundations of research. Today traditional common and uncommon sense archaeology is reorganising (cf. Callmer 1995) and striking back. In rare cases it is fiercely dispatching itself into an inter-war state (cf. Rundkvist 1995). This situation calls for a methodological discussion.

History and archaeology are often located at different departments, and the terms 'historical archaeology' and 'archaeological history' may be said to be contradictions in themselves. The will to keep the subjects apart seems, however, to reflect two research traditions within academia rather than two fundamentally different ways of studying the past.

Nonetheless, when asked to define a difference between history and archaeology the educated interview person will start by pointing out the differences in time - archaeology studying the more remote past - and proceed with the source material, drawing attention to the difference between material and written records. Archaeology, however, has no end as long as material culture exists. And since the distinction, when it comes to meaning, between material sources and language, regardless whether language is made up by oral or written material, does not guide us other than occasionally in the present, there is no reason to believe that people in the past were troubled by the distinctions, despite the fact that writing is a young and specific technique (cf. Andrén 1988).

This means that most people, like Orser and Fagan (1995:4 ff.), would consider historical archaeology to be the archaeology of the recent past, that is, 'the archaeological study 
of people documented in recent history' (Orser \& Fagan 1995:5). In this connection we would take archaeology to mean the study of people through material sources, such as artefacts, ecofacts and so on. Orser and Fagan continue to discuss their definition on the basis of three earlier ones which make up the roots of their own. First they point to the post-prehistoric character of historical archaeology, generally referring to Robert Schuyler and Grahame Clark (e.g. Schuyler 1970; Clark 1957). Later they bring in the anthropological and ethnoarchaeological perspective by referring to William $\mathrm{H}$. Adams' study of Silcott (1977), and they end by marking out the world-wide modernity of the subject by quoting James Deetz's definition (Deetz 1977). In my opinion their discussion should be considered educated but traditional, and I base this upon the fact that the authors note that the use of the historical record is a methodological approach in its own right when they state that historical archaeology employs both archaeology, history and anthropology. At the same time they point out that the quality of the source material available for a given study rests on the ability to study the world and its people in parallel ways representing archaeology, anthropology or history. According to Orser and Fagan, the methodological approach of historical archaeology treats its material with respect to the demands of the traditional disciplines. So in their view an archaeological context i.e., an arranged archaeological source material cannot be understood in the same way as a piece of oral information, a work of art or a section of a legal text. In my opinion their point of view is problematic.

Traditionally speaking historians do write about texts, but at the same time they want their narrative to reflect a reality framed by a material rather than a fictive world, and they do not want the material gruesomeness of the battlefield to disappear. If, therefore, we ask questions about what went on in the material world in the past, then it goes without saying that texts which try to elucidate that question by description or by reasoning are valuable documents. Their value grows if they reflect formal institutions rather than informal ones, since formal institutions, and texts reflecting them, are in themselves the result of an achieved and quite precise consensus about what goes on and should go on in the material world. This means that history and several of its sources share the same purpose, namely that of reflecting formal institutions which, due to their being formal already in the past, would seem to have existed.

It may be hard to draw a line of demarcation between formal and informal institutions, but, nonetheless, we do recognise a good many formal ones such as land taxation, the legislative system, the organisation of the Church and so on. Even some of the informal ones such as dating, having a relation, and bringing up children are easy to point out. There is, moreover, no doubt that in my sketch of traditional history as a discipline the subject is in itself responsible for the production of a lot of formal institutions which are from the very beginning documented, that is, made equal, or almost equal, in intent to their own documents.

Today most historians are probably bored by the traditional core of their discipline, e.g., by studies of formal institutions such as the analysis of a small factory company as a legal body based on the archives of the firm itself. The ultimate reason for this should be sought in the intellectual change which began to manifest itself during the Enlightenment, when the study of informal institutions and social norms started to puzzle the intellectual. For the study of formal institutions it raised questions about the character of the formal in a given institution and the factuality of such institutions. Much of the methodological work within history as an academic discipline aimed at securing the factuality of the formal as a true reflexion of the past.

Turning to archaeology, it is easy to recognise a discipline concerned with the mate- 
rial outcome of mostly informal institutions and social norms in all kinds of societies. It is, moreover, of little theoretical interest to the archaeologist whether the recovered material ties in with formal or informal institutions. Traditionally the emphasis has been on the material items, on sorting, on the chronology of things and on the production of material patterns. Little by little, however, a sociological sphere of interest is reforming archaeo$\operatorname{logy}$, and today traditional archaeology is felt to be either boringly free of values or unconsciously biased.

Focusing upon informal institutions, social norms, and matters of social psychology tends to break down established categories of source material and in the long run it leads to the deterioration of academic disciplines defined mainly by a specific kind of source. As it happens this is true of history as well as archaeology, and new methodological approaches are therefore needed in order to facilitate a more efficient usage of any kind of source material. It is not enough to bridge investigations based on different autonomous disciplines.

\section{A SCANDINAVIAN DISCUSSION}

The existence of the discipline Medieval Archaeology in Lund has created an ongoing debate about historical archaeology. The debate is often dominated by the clash between history and archaeology, as ways of doing research. The conflict emerges when we detect that the diplomatic and chronological limitation 'medieval' may well be equated with the general term 'historical'. Instead of denoting an unobtrusive cousin, Medieval Archaeology is frankly speaking historical archaeology.

In the journal META there has been at least one very significant debate during the last decade, namely, the one provoked by Anders Andrén's introduction of the concepts 'manifest' and 'latent'. They were introduced in order to emphasise the varying qualities of written and material sources. The concepts ought not to have created the negative response which they did, since they are quite useful, for example, when it comes to discussing the qualities of bulk finds with an obvious shortage of contextual ties. Of course there are many qualities in 'ubiquities' such as shoe leather waste, but they are different from those of a precise description of a shoemaker's workshop. In the latter we may expect a lot of manifest concepts to be at hand, while the former will have a more latent connection with the past. Without being better, several texts are conceptually more manifest than a sample of potsherds.

Instead of evoking dicta - like the one produced by Christophersen (1992) which over emphasised our being first and foremost archaeologists - and other caveats which reflected the inferiority complex of the archaeologist in his or her relationship with history and historians, Andrén's concepts ought to have provoked a methodological discussion about the possibility to use the same kind of analytical pattern on sources of different complexity and quality. Christophersen satisfied himself by pointing out the conflict between the different sources, but saw no solution to the methodological problem, that of integrating archaeology with history. Christophersen's predicament seems to result from his reluctance to acknowledge the discrepancies between the academic disciplines involved in the study of the past. So while blocking itself with rather traditional views on archaeology and history, the Scandinavian discussion did nonetheless contain an opening in Andrén's dichotomy.

\section{WAYS OF READING}

For the purpose of a general discussion about historical archaeology, we may as well pick out the problem of the Middle Ages in Northwest Europe. That, in the end, was what the META-debate was all about. Taking this problem for granted, it is fair to say that the written material has ceased to grow, aside from the occasional piece of parchment, rune- 
stone or inscribed helmet. The corpus can, moreover, be surveyed. The archaeological source material on the other hand is growing rapidly and pattern production is therefore an ongoing process in a research where there can be no survey of the source material. Pattern production is often simple enough, but the archaeological material is nonetheless growing in complexity as well as in quantity. For that reason the need to reread medieval texts is strongly felt by archaeologists.

It is of minor importance whether the interaction between material and written sources starts by rereading a text in a new key or by re-examining a set of artefacts in trying to make a new interpretation. The essence is the principle that critical rereading or re-examination is a way of creating a fusion between cores of traditional disciplines such as history, linguistics, art history, history of literature or archaeology. It is the evolutionary and additive aspect of knowledge production that matters. For that reason and for the sake of the debate, it is reasonable that those representing the discipline which brings forth the new source material should also advise new guidelines for the analysis of the stagnating corpus.

In order to meet our needs, critical rereading should take place on three different levels: the conceptual, the intentional and the structural. As labels the expressions cover a way of reading which proceeds from the limited and formal to the open and discursive. In terms of understanding the past in the present, the labels signify a flow from the most conscious to the unconscious or unreflected normative conduct of those who produced the source material. The labels signify rather arbitrary sections into a continuously changing relation with the textual, but as long as the method seeks to study different patterns under the same analytical labels the sections can be defended. In connection with material patterns, this kind of textual study is becoming more and more common. Ian Hodder's study of the domestication of Europe (1990) is easy to understand on a conceptual, an intentional and a structural level and so is Christopher Tilley's phenomenology of landscape (1994). The approach can also encompass material as well as written sources in one and the same study (cf. Herschend 1995).

There is a link in critical rereading to Andrén's discussion mentioned above, and that becomes even more apparent when we look into his studies from the 1990s, for example, the one dealing with gold bracteates (Andrén 1991). There are three distinct analytical levels marked out by the disposition of the study, and they may be labelled according to the above. The conceptual and also most manifest level is the linguistic one, on which three Germanic words are considered to parallel three Roman ones used to define an emperor. The second and less manifest level is a discussion of the political and ideological intent behind the iconography of the bracteates. This intentional level is obviously less formal than the first but still more manifest than the third level, on which the distribution of die-linked bracteates is seen as a way of mapping areas of political connections. This mapping is a typical structural analysis inasmuch as the distribution is the result of a great number of normative rather than outspoken intentional actions. Therefore the bracteates give a very latent picture of possible political areas. Making use of the bracteates in these different ways singles out different subsets or materials with different qualities; and contrary to what Andrén's opponents may believe the differences do not grade the sources in categories such as the best or the worst. Nobody would for methodological reasons, have found it correct to leave out any of the three approaches.

With the relative concepts 'manifest' and 'latent' Andrén, in my opinion, wanted to link the source material to a dichotomy which ties in with different analytical and conceptual methodological levels. I think there is a ge- 
neral methodological point in widening the perspective, and propose a standard analysis of material as well as written sources. I have chosen to exemplify the approach with a critical rereading of some texts in order to stress that only through critical rereading can we grasp the methodologically singular qualities of historical archaeology. Whether or not historians or linguists will engage themselves in critical rereading is of minor interest, but expert knowledge is more accessible if we consider critical rereading in a common methodological key.

\section{AN EXAMPLE}

The outlined key of reading could often lead to a rather lengthly discussion, but by choosing a clearly concept-governed example the principles may, for the sake of methodology,

\begin{tabular}{|ll|}
\hline Land & land. Sing: n (lond) 2197; g \\
& (landes) 2995; d (lande) 1623, \\
& 1913, 2310, 2836; a (land) 221, \\
& 242, 253, 580,1904, 2062, 2915 \\
& (lond) 521, 1357, 2471, 2492. \\
& Pl: g (landa) 331. \\
& \\
Compounds & ealand, elland, Fresland, Scede- \\
& land. \\
& landbuend, land-dweller, 95, \\
& 1345. \\
& landfruma, prince of the land, i.e. \\
& king, 31 \\
& landgemyrce, land boundary, 209 \\
& landgeweorc, land work, i.e. \\
& stronghold 938 \\
& landwaru, people of the land \\
& 2321 \\
& landweard, land-guard, i.e. coast- \\
& guard 1890 \\
& londriht, land-right gs. -es, v. \\
& 2886 \\
&
\end{tabular}

Tab. 1. Land and its compounds in Beowulf. The underlined occurrences are the ones discussed here. After Klaeber 1950. be exemplified in a relatively short discussion. I have chosen to focus upon the usage of the word 'land', that is, land or lond in the Beowulf poem (Tab. 1).

The word land falls into two groups. One is a group in which land is synonymous with the word 'country' or the general phenomenon, land as opposed to sea or sky. The other group, underlined in the above table, consists of four cases in which land is a more or less well-defined fiscal unit of some kind, namely, a piece of land which one may give away. The last word londriht, 'land-right', hardly ties in with this usage, but it has been understood to do so, for example by Nickel (1976:179) and must therefore be discussed. It is characteristic that only in the second part of the poem is 'land' used to designate something which may be granted or gained. Disregarding the general usage, the specific usage may be illustrated by the following quotations:

\section{1) Pat he on Biowulfes bearm alegde,} ond him gesealde seofan Pusendo,

bold ond bregostol. Him was bam samod on zam leodscipe lond gecynde, eard edelriht, odrum swizor side rice bam der selra was.

that (a sword) he laid on Beowulf's lap and gave him seven thousand, hall and throne. For them (i.e. Beowulf and Hygelac) there was for both together in that country inherited land, estate by native right, for the other (i.e. Hygelac) a larger realm, for him who was there the better. (vv 2194-2199)

2) earferum lafde, swa deðे eadig mon, lond ond leodbyrig, to he of life gewat.

he left for the descendants, as a prosperous man does, land and folkburgs when he departed from life. ( $v \vee 2470-2471$ )

3) Ic him Pa mazmas, pe he me sealde geald at guze, swa me gifede was, leohtan sweorde; he me lond forgeaf eard edelwyn. 
The treasures that he gave me I paid him back in battle, as it was granted me (i.e. by fate), with the gleaming sword; he gave me land, a delightful homeland. (vv. 2490-2493)

4) sealde hiora gehwcedrum hund Pusenda landes ond locenra beaga, - ne dorfte him da lean ozwitan;

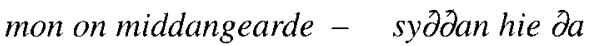
merda geslogon

He gave each of them a hundred thousand of land and linked rings (i.e. payment rings) no man on earth has good cause to reproach him for those rewards - since they won glory by fighting. (vv. 2993-2996)

\section{5) $\mathrm{Nu}$ sceal sincPego ond swyrdgifu,} eall edelwyn eowrum cynne, lufen alicgean; londrihtes mot Pare magburge monna aghwylc idel hweorfan, sydzan cedelingas feorran gefricgean fleameowerne, domleasan dad.

Now shall the love, the treasure taking and sword giving, all the delight for your race in the homeland, cease; each one of the men of the clan must move about empty of landright (i.e. lose land-right), when nobles from afar get to know of your flight, an undiscerning (i.e. inglorious) deed. (vv. 28842890)

The split and underlined expression londrihtes idel hweorfan, echoes the wording of a sentence or the verdict of a thing-assembly. The way it is treated by the poet indicates that it is a stock phrase and difficult to miss even when broken into pieces. It also sounds like an archaic formulation of a defaming punishment, implying that those deprived of land-right were not allowed to settle. The phrase echoes Caesar's account of the Germanic custom each year of distributing land among themselves (Book VI:22; 1-2). If we are not given land to support ourselves we must either find a new place where we are allowed to settle or move about as outlaws. In the German and Scandinavian languages one can still describe someone's loss with a 'go-construction' without actually depicting people walking around. In the poem, however, the original meaning is close at hand since the geographical dimension of 'losing land-right' is one of the points of the passage. The text is Wiglaf's speech to Beowulf's deceitful retainers, and the consequences of their conduct turn out to be the end, not just of Beowulf, but, of the whole Geatish nation. That is a very good reason to emphasise the harshness of the judgement, but it also shows that londriht is a most general word and a cardinal concept which cannot be translated as Landbesitz, that is, estate (Nickel 1976:179). So before a critical rereading can take place, there is nearly always a discussion of critical research history to carry out.

\begin{tabular}{|lll|}
\hline Meaning & occ. & T.p.q., from $N N$ and onwards \\
\hline 'country' or 'land' in general & 8 & Æthelberht, ca. 600? AD $\rightarrow$ \\
defining someone as linked to land & 8 & Ine, ca. 690 AD $\rightarrow$ \\
piece of land or estate* & 4 & Ine, ca. 690 AD $\rightarrow$ \\
bocland, i.e. granted land & 3 & Alfred, ca. 890 AD $\rightarrow$ \\
& & \\
& \\
\hline
\end{tabular}

Tab. 2. The word land in the laws of the earliest English kings. Based on Attenborough 1922. 


\section{THE CONCEPTUAL LEVEL}

We may compare as we please, but since giving away and receiving land by charter or by will is eventually becoming a most formalised phenomenon, it is fair to start by checking the use of the word land in the laws of the earliest English kings, for example, as published by Attenborough (1922). In so doing we can single out at least four different ways of giving meaning to the word. They are summarised in Tab. 2.

The kind of land that we hear of in $\mathrm{BeO}^{-}$ wulf is a relatively late legislative phenomenon and it is obviously given the special term bocland - i.e. 'bookland', - which seems, however, to be a term unknown to the Beowulf tradition. This indicates that the poem is referring to a phenomenon which had not yet tempted the legislative diligence of kings, although it was already a practice to give away land. The fact that the word appears only once in Alfred's laws, while a large number of paragraphs are regulating all kinds of intercourse, assault and fighting, supports the opinion that bocland was not a major legislative problem when the Beowulf poem was formed.

It would seem that the Beowulf quotations allude to land as a formal concept inasmuch as we are given to understand that the value of this kind of land can be estimated, as well as given away and received as compensation or by will. There is security in land and also qualification and commensurability either with gold, in the form of payment rings, or with martial services rendered. Land, moreover, is backed by rights, albeit in custom, and in such buffers there is a remote connection with the londriht discussed above. The quotations show us the framework for a land reform about to be launched. This reform is based on the defensible right of kings and aristocracy to distribute land between them. Yet there is a conspicuous lack of appropriate terms and concepts: the unit in which land is measured is not mentioned, and the lack of the term bocland renders the term land a confusing vagueness. Without formal terms to designate these concepts, we may well jeopardise the whole project of individual land control.

Once we are aware of the vagueness of the concept, the indisputable right of the rich to give and receive land creates a striking discrepancy, and therefore it seems right to conclude that the theory of individual land control is present in Beowulf, but as yet without any well-defined (i.e. institutionalised) practice to refer to. Early charters and wills, together with the occasional mention of bocland in laws, are obviously only weak indications of a formally accepted practice. Not until the production of the first gross forgeries of charters should we consider the custom of giving away land a formally accepted practice. This means that not until the middle of the 11th century, with such forgeries as the 'foundation' charters from Saint Augustine's Abbey in Canterbury (Kelly 1995:LXIV ff.), may we believe in the formalised character of the grant. The point in the three forgeries is obviously not to claim some pieces of land, but to attest to the existence of the Abbey as early as $605 \mathrm{AD}$. Granting land is just a means to turn the head of the reader, and the success of the forgery is dependent on our being prepared to consider the granting of land a perfectly normal and formalised and legally indisputable matter. Early charters were probably more interesting as informal expressions, material contexts and characters than as formal legal texts.

\section{THE INTENTIONAL LEVEL}

Instead of concentrating on sharp-defined formal concepts of granting and receiving land, the Beowulf tradition focuses upon what it believes to be the deep roots of the tradition and on its moral implications. When the singer defends the granted land, with reference to practice in the past, he shows himself to be too preoccupied with the general idea of granting, and the historical aspect in the passages is no doubt just an 
argument in defence of the moral rights of kings and aristocracy. This is something which characterises the whole poem. I shall leave this aside and instead concentrate upon the intentions associated with the verses themselves, knowing that intentions on different levels can clash in a meaningful way.

When we look at the four questions, it strikes the eye that the poet can never just mention the lavish gift. He must always draw attention to some sort of explanation, implying that what has happened cannot be criticised. In the first quotation we are given a background to the fact that Beowulf gets a large estate, and it is pointed out as some sort of explanation, albeit obscure, that this did not imply a qualitative change in his status but a mere quantitative change which was thus not much to grudge. Beowulf already owned the same kind of land as the king, but the king, having more of it - i.e. inherited land, - gave him some of his. Even in the second quotation we are made to understand that he who owns much may also dispose of his wealth as best he pleases. We are informed that King Hrethel did the normal thing, but having the normal thing especially pointed out to us, as indeed the normal, is odd.

The first two quotations are descriptions in which the author has decided indirectly to explain something to us. The last two are taken from monologues by Beowulf. The first of these indicates that the grant in question was part of a measure-for-measure bargain, in which give and take balanced each other. In the last quotation, finally, we are quite bluntly told the precise reason why grants are fair. Grants and gifts are fair if they are compensation for successful fighting for the king. This is the retainer's point of view, and the Beowulf poet intends to defend the retainers against the common landowners.

Looking back upon the four quotations, it becomes obvious that they build up to the last one in which the explanatory force of the narrative is most clearly stated. Reproach is hypothetically set up against righteousness, and reproach cannot be defended. It is the intent of the singer to pair gift-giving with explanation and to arrange the explanations in such a way that the listener after 800 lines, the equivalent of an hour or so, has got the message.

This means that when we discuss the obvious intent, namely that of explaining how grants are balanced by glorious deeds among the aristocracy, we detect a structural and perhaps more normative trait, namely the rhetoric escalation as an argument in itself.

\section{THE STRUCTURAL LEVEL}

Structure is a matter of following conventional patterns, but also a way of creating a composition which satisfies the poet. We have noticed the possibility of rhetoric escalation, and in the above example of the landright we may have an illustration of the poet's wish to include what was perhaps a wellknown legal prose expression, londrihtes idel hweorfan. The expression lacks poetical quality, but it reminds us of a harsh and worthwhile reality and therefore needs composition. In order to fit the expression into the poem, the poet works with the split both as a poetic quality and a way of getting the expression to fit the metre. So instead of saying monna aghwylc thare magburge mot londrihtes idel hweorfan - 'each man of the clan must be deprived of land-right' - the poet decides to single out two essential words and put them next to each other at the beginning of the sentence where they stand most visible, or rather hearable, and in obvious if not splendid isolation. He can apply what in later Scaldic verses become a common grip, knowing that the end of the stock phrase, idel hweorfan, makes a very good reminder and cadenza. He must, however, have some kind of fill between londrihtes mot and idel hweorfan in order to make land-right stand out.

Structural composition, which shows something of the poet's freedom within the normative system, is often hard to prove. 
The other kind of structure, the one signified by rather strict conventions, is naturally easier to detect, but it should be remembered that the compositional freedom exists parallel to stricter norms (cf. Foley 1983). If we turn to the conventional patterns, one of them can be seen in the tendency not to give just one thing. This tendency may have been real, but at the same time it fits metrical and alliterative patterns very well. Therefore three of the gifts are: bold ond bregostol; lond ond leodbyrig; landes ond locenra beaga.

All alliterating half-strophes are not equally good when it come to the interplay of the vowels, the stressed consonants and the rhythm. A half-line like, licsyrce ond lond 'coat of mail and land' - is extremely bad from a rhythmic and vocalic point of view, and it lacks a shift between the stressed syllables which would have helped the line to come to an end. The rhyming, ond lond, makes it even worse. Lond ond leodbyrig on the other hand is a nice half-strophe. The rhythmic pattern is simple and repeated. The interplay of the vowels in lond and leod gives the impression of the two words being two aspects of the same matter, and the shift from leod to byrig makes a good cadenza.

The interplay of the vowels a, e and o is typical of the alliteration with land or lond, namely:

(v 2197) on tham leodscipe lond gecynde, (v 2471) lond ond leodbyrig,

( $v$ 2492) leohtan sweorde; he me lond forgeaf ( $\vee 2995$ ) landes ond locenra beaga

It is, however, obvious from the quotations that land is the primary word while leod, and especially leohtan and locen are there for conventional poetic reasons. Leod, people, is no doubt connected with land, but that is hardly for conventional reasons only, since land and people may well be understood to be complementary. In the poem leod is, however, not a very essential word, and contrary to land which in this connection is always carrying the alliteration, leod does so only in 20 per cent of sixty odd cases.

Having reached this far in the structural analysis and having detected some of the more or less unconscious habits of the author or the oral tradition, the aim of the analytical level has been reached. The goal consists in the connection formed between the intentional expressions and the more unreflected norms guiding the poet. In this case we have reason to believe that land was the essential word and that a poetical pattern was built around it. That is obviously a reassuring result when the concept land is in focus.

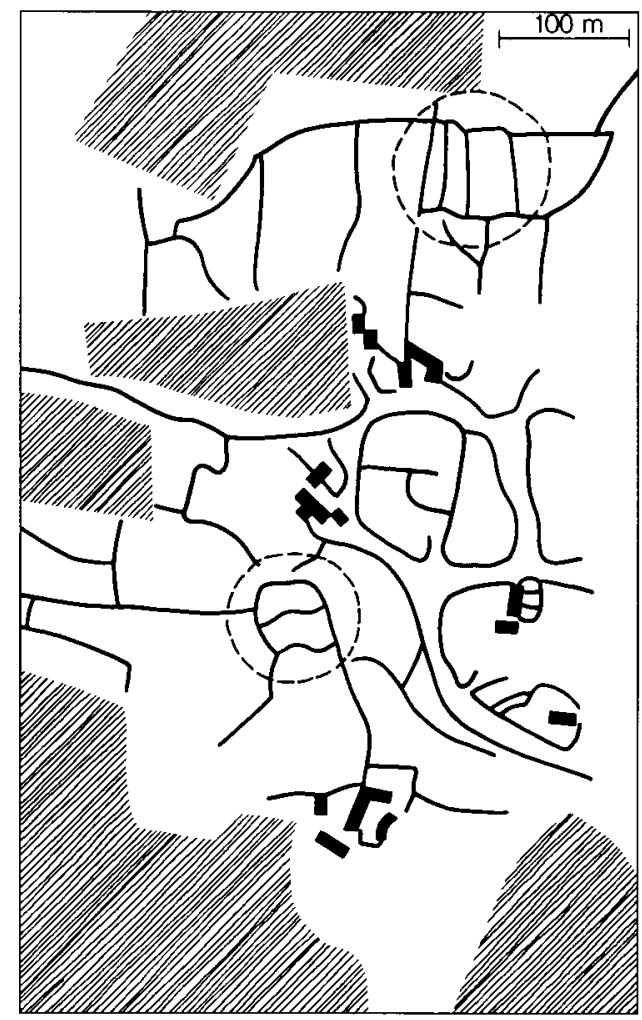

Fig. 1. Divided fields, i.e. measured land, in the Ölandic settlement system just north of the village Övetorp in Algutsrum parish. Based on the Economic Map and field observations. Hatched areas designate modern disturbances. 


\section{A PARALLEL REREADING}

The archaeological study of the kind of land that we read about in Beowulf may seem difficult to carry out, but it is by no means impossible if we follow the three analytical levels. My background has led me to find a suitable material on Öland in the Baltic, namely, the fenced arable land from the middle of the first millennium AD (cf. Edgren \& Herschend 1983; Fallgren 1993 with ref.).

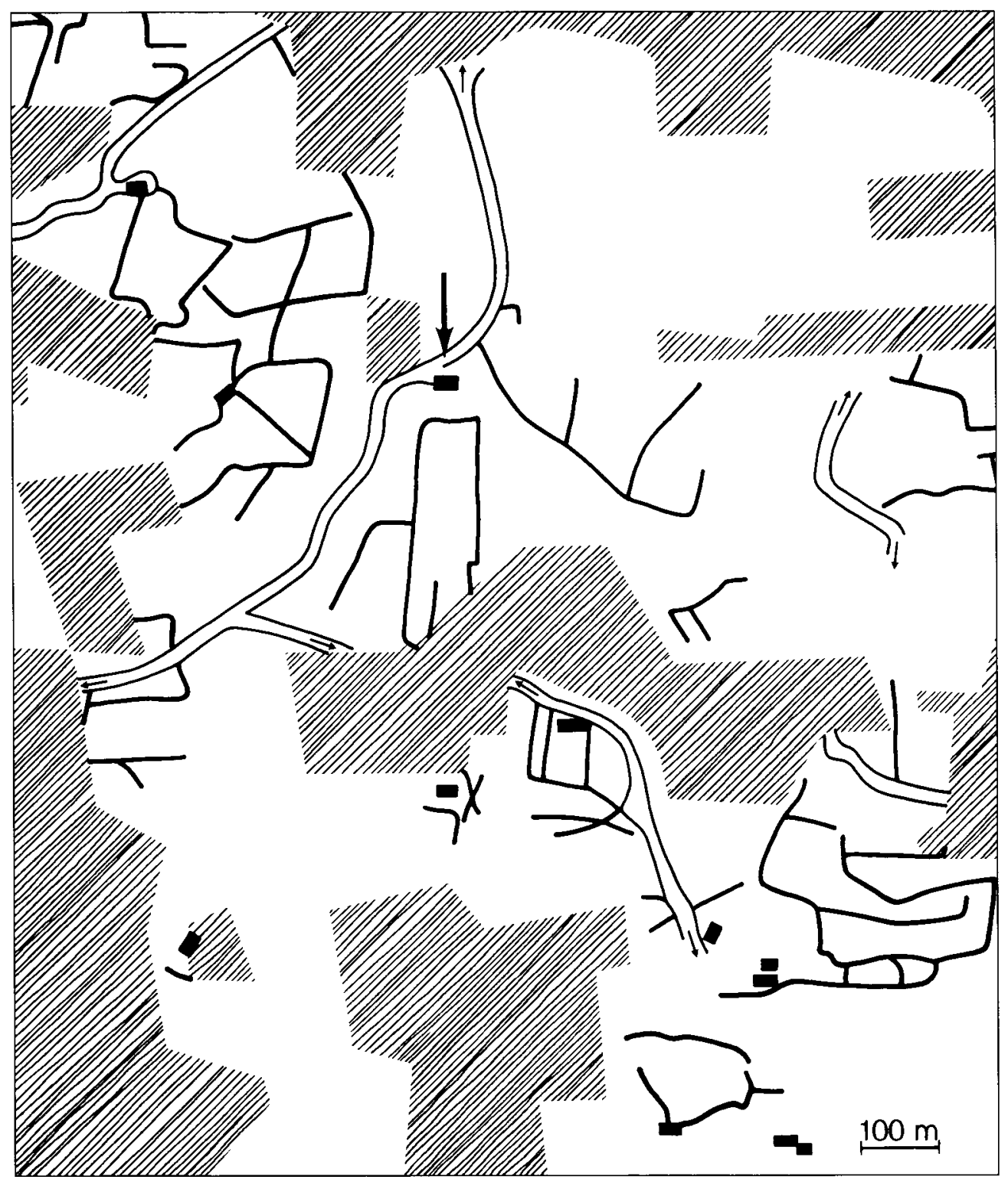

Fig. 2. Roads through a system of fenced fields on Öland. The small farm (ancient monument, Glomminge parish no. 21) at the pointer has been provided access to the open grassland by means of a long road, its only connection with this kind of land. Based on the Economic Map and field observations. Hatched areas designate modern disturbances. 
On the conceptual level we can point to the partition of the fenced land by measured division (Fig. 1). The measure in itself has nothing to do with the quality of land which it divides, and therefore the division is a formal definition of a piece of land which is going to be willed to an heir or given away in accordance with one of several other possible reasons. This kind of partition is not commonly recognised on Öland, and it has not been studied in a systematic way. That, however, does not change the value of the example in this case, since it stills suffices to show that land as a formal phenomenon which may be granted or given away has its denotations in Beowulf as well as on Öland.

If we proceed to a more intentional level the examples in the Ölandic scene multiply, but if we concentrate upon the problem in Beowulf, namely that of the right to change patterns of possession, then we can point out the following: The abandonment of the fenced land on Öland (cf. Näsman 1988 with ref.) is in itself a sign of a great potential for bringing about large-scale change. On the other hand there are also signs of a great unwillingness to change the pattern of rights and possession. That can be seen in the example of the very small farm which, in spite of its being situated in the middle of a large fenced area, is nonetheless given access to the common grassland by means of a very long road (Fig. 2). The development of the fenced areas is the result of a long-term process, gradually involving more and more farms in a more and more complex system. Therefore the building of the fenced road and the abandonment of the whole system are probably relatively close to each other in time, thus signifying the same kind of clash between preservation and change that we noted in Beowulf.

Turning to the structural level, it becomes clear that access to fenced and unfenced land

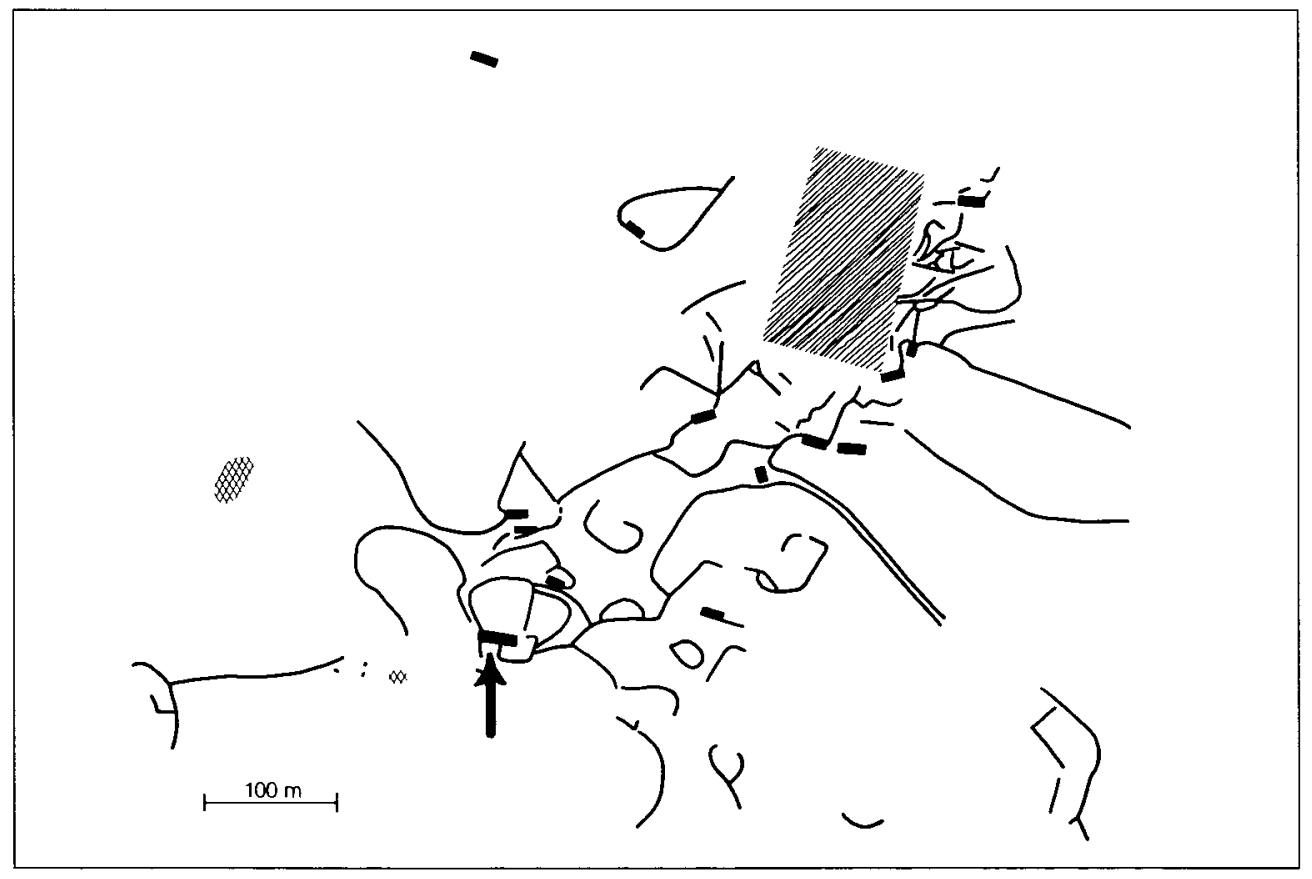

Fig. 3. The Iron Age village of Rosendal with its characteristic situation of the dominating farm (at the pointer). Based on Fallgren 1993. Hatched areas designate modern disturbances and cross-hatched areas graves. 
is essential to any farm. The well-preserved village, which is today called Rosendal (Fig. 3 ), is a good example of this. It is, however, also an example of a very common village pattern showing us a village consisting of a large farm in a corner or end position next to the most prominent burial monument, and the rest of the farms attached to the large one (cf. the southernmost farm in Fig. 3). The large farm occupies the best position in the village. It is in immediate contact with half the village land and via the roads its animals may easily pass through the fenced area. This structure shows a right to land and a pattern of possession as well as the dependency of the system on the large farm. This dependency may be seen also in more basic structures, for if we analyse the morphology of the fences they seem to fall into three groups, two of which encompass fields and one of which breaks through the fields and sends out tentacles in the open grassland. If we single out these elements it becomes obvious that
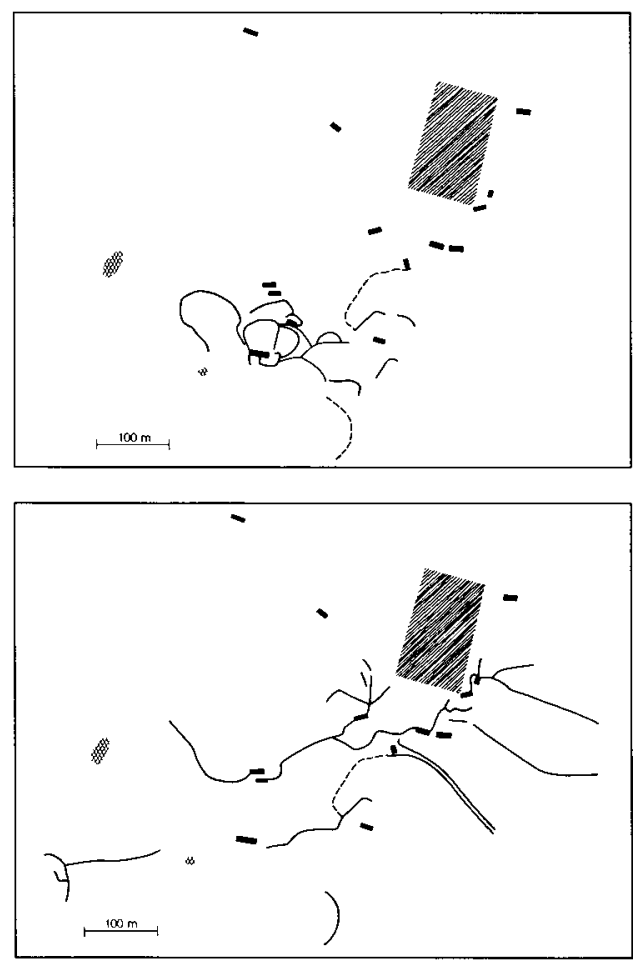

their form is dependent on the position of the large farm. Those which encompass the fields are either concave, seen from the point of view of the dominating farm (Fig. 4a), or partly convex seen from the same point of view (Fig. 4b). Enclosed fields are relatively common even next to the main farm, but fences which are convex from the point of view of the dominating farm are few and peripheral. The tentacle fences, finally, are designed in such a way that the main farm and others in the centre of the village will have access to the grassland on all sides of the village (Fig. 4c). This means that the position of the main farm is indeed dominating, and in principle half the village seems to be dominated by it. The pattern of the fences indicates that the relationship to land as fenced or open but dominated is as deeply rooted in the mind of the Ölandic farmers as in that of the singers of the Beowulf tradition. Moreover, it seems as if land originated from the large farm, thus creating the main

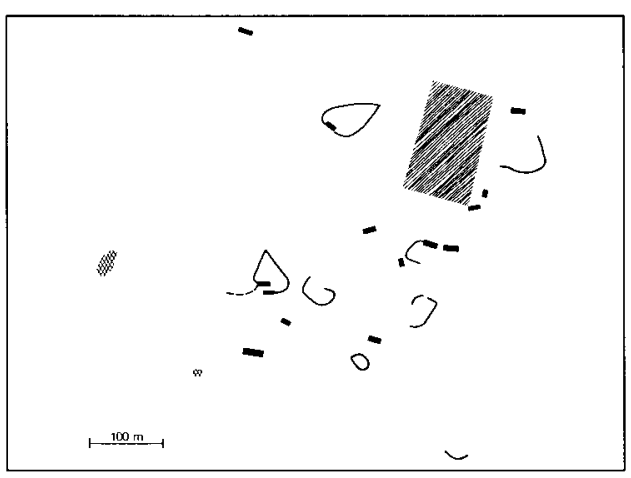

Fig. 4a-c. An analysis of the Rosendal village. a) enclosures bending away from the dominating farm. b) Enclosed fields or enclosures bending towards the dominating farm. c) The fences leading out into the open grassland. Based on an analysis of Fig. 3. Hatched areas designate modern disturbances and cross-hatched areas graves. 
preconditions for the problems and possibilities in land that the poem discusses.

\section{CONCLUSION}

When archaeological material, the physical remains, constitutes the major and growing part of the sources, it is fair to talk of an archaeology. But it is not wholly satisfying to call it historical. On the contrary, according to the methodology sketched here it ought to be called textual, thereby implying that it works equally well with all kinds of source material. Textual archaeology is only from a technical point of view restricted to a certain period. The parallel term, 'textual history', is in the same way a technical term signifying that the written material dominates period and research. The textuality is significant of both. The methodological approach of a textual archaeology is critical rereading. The term designates the evolutionary and additive approach to research which must characterise textuality.

The above critical rereading does the following: It makes three sections into a human work or a manifestation of humanness. The sections are meant to reveal different levels of consciousness in the work. Linking consciousness to a certain conceptual understanding makes it possible to deconstruct the work without risking that it cannot later be recreated. There are probably very many levels of consciousness on which a work could be understood, but if it can be shown to be consistent on three levels pointing to each other then the understanding is probably relatively coherent.

That is why it was necessary to reflect the conceptual level in a more formal concept of granting land, since consequently the informal concept of the Beowulf poem pointed to a more intentional usage of the word lond. It was equally interesting that the intentional analysis pointed to the conceptual level as well as the structural one, inasmuch as the intentional composition is indeed connected with a more unreflected usage of structural norms.

The 're-' in rereading is rooted in the fact that the material in question has been interpreted a great number of times and certainly with more or less reference to one or two of the levels indicated here, but perhaps not in an equally methodically conscious way to all three levels. In my opinion all three levels are, nonetheless, necessary for the reasonable analysis. From a theoretical point of view it is the levels that matter, as well as the exposure of an inner correspondence between different levels of understanding. This correspondence can be found both in material and written sources.

What do we gain from rereading Beowulf and the fenced land on Öland? First and foremost we get comparable understanding of a concept. Secondly, we engage ourselves in a discursive interpretation of the past rather than a reconstructive narration establishing facts. Both these outcomes are to my mind advantages.

\section{REFERENCES}

Adams, W. H. 1977. Silcott, Washington. Ethnoarchaeology of a rural American community. Reports of Investigation 54. Pullman Laboratory of Anthropology, Washington State University.

Andrén, A. 1988. Ting och text - skisser till en historisk arkeologi. Meta 1988:1-2:15-30.
- 1991. Guld och makt - en tolkning av de skandinaviska guldbrakteaternas funktion. In: C. Fabech \& J. Ringtved (Eds). Samfindsorganisation og regional variation. Århus: 245-256.

Attenborough, F. L. 1922. F. L. Attenborough (Ed. and trans.). The Laws of the Earliest English Kings. Cambridge. 
Caesar, G. J. 1965. E. C. Kennedy (Ed). De bello Gallico. Cambridge.

Callmer, J. 1995. Arkeologins grundläggande perspektiv. Fornvännen:29-44.

Christophersen, A. 1994. Mellom tingenes tale og tekstenes tyranni. Meta 1994:2:70-87.

Clark, G. 1957. Archaeology and Society. London.

Deetz, J. 1977. In Small Things Forgotten. The Archaeology of the Early American Life. New York.

Edgren, B. \& Herschend, F. 1980. Arkeologisk ekonomi och ekonomisk arkeologi. Fornvännen:7-21.

Fallgren, J-H. 1993. The concept of the village in Swedish archaeology. Current Swedish Archaeology, Vol. 1:59-86.

Foley, J. M. 1983. Literary and oral tradition in Old English and Serbian poetry. Anglo-Saxon England 12:183-214.

Herschend, F. 1995. Friends of Trimalchio's. Tor 27:1:269-310.

Hodder I. 1990. The Domestication of Europe. Structure and Contingency in Neolithic Societies. Oxford.
Kelly, S. E. 1995. Charters of St Augustine's Abbey Canterbury and Minster-in-Thanet. Anglo-Saxon Charters IV. Oxford.

Klaeber, F. 1950. F. Klaeber (Ed). Beowulf and the Fight at Finnsburg. London.

Nickel, G. 1976. G. Nickel (Ed. and trans.). Beowulf und die kleineren Dänkmäler der altenglischen Heldensaga Waldere und Finnsburg. Bd. 1-2. Heidelberg.

Näsman, U. 1988. Den folkvandringstida? krisen i Sydskandinavien. In: U. Näsman \& J. Lund (Eds). Folkevandringstiden i Norden. Århus: 227-255.

Orser, C. E. \& Fagan, B. M. 1995. Historical Archaeology. New York.

Rundkvist, M. 1995. Kampen för "teoretisk korrekthet" inom arkeologin. Fornvännen:253256.

Schuyler, R. L. 1970. Historical archaeology and historic sites. Archaeology as anthropology. Historical Archaeology 4:83-89.

Tilley, C. 1994. A Phenomenology of Landscape. Places, Path and Monuments. Oxford. 